\title{
Mother-offspring stable isotope discrimination in loggerhead sea turtles Caretta caretta
}

\author{
Nicole S. Frankel ${ }^{1}$, Hannah B. Vander Zanden ${ }^{1, *}{ }^{\text {, Kimberly J. Reich }}{ }^{1}$, \\ Kris L. Williams ${ }^{2}$, Karen A. Bjorndal ${ }^{1}$ \\ ${ }^{1}$ Archie Carr Center for Sea Turtle Research and Department of Biology, University of Florida, Gainesville, \\ Florida 32611, USA \\ ${ }^{2}$ Caretta Research Project, Savannah Science Museum, PO Box 9841, Savannah, Georgia 31412, USA
}

\begin{abstract}
Knowledge of foraging strategies has significant implications for the conservation of endangered loggerhead sea turtles Caretta caretta. Stable isotope analysis is a useful tool in studying the ecology of marine consumers, as nitrogen and carbon isotope ratios $\left(\delta^{15} \mathrm{~N}\right.$ and $\left.\delta^{13} \mathrm{C}\right)$ may reflect an organism's patterns of diet and habitat use. However, obtaining samples for analysis from the study species can be difficult. For female loggerhead turtles, there is a limited time window in which to collect samples while the turtles are nesting. In the present study, we investigated mother-offspring stable isotope relationships and the potential for sampling hatchling loggerheads to gain information about nesting female populations. Epidermis samples were collected from 29 nesting females and 47 of their hatchlings on Wassaw Island, Georgia, USA. The $\delta^{15} \mathrm{~N}$ and $\delta^{13} \mathrm{C}$ values of maternal and offspring tissues were compared to determine the discrimination, or difference, in isotope values. Hatchlings that were sampled after being discovered dead in the nests had significantly different discrimination values from those that were freshly dead, suggesting that decomposition affects the reliability of isotope ratios. Therefore, we suggest using fresh hatchling samples. Hatchling $\delta^{15} \mathrm{~N}$ and $\delta^{13} \mathrm{C}$ values were significantly correlated to the isotope values of their mothers. Freshly dead hatchlings had significantly higher $\delta^{15} \mathrm{~N}$ values and lower $\delta^{13} \mathrm{C}$ values relative to their mothers, and there was little variation among hatchlings within a nest. These discrimination factors can be applied in the future to determine maternal isotope composition from hatchling tissues and evaluate trophic relationships and foraging strategies of nesting females without sampling them.
\end{abstract}

KEY WORDS: Discrimination factor · Carbon isotopes $\cdot$ Nitrogen isotopes $\cdot$ Sea turtle $\cdot$ Hatchling Decomposition · Epidermis

\section{INTRODUCTION}

The loggerhead sea turtle Caretta caretta is a generalist marine consumer that is known to feed on a wide range of prey (Bjorndal 1997). Yet studying the resource patterns of widely dispersed organisms can be difficult and expensive. In recent years, stable isotope analysis has been used as a tool to examine the foraging ecology of marine consumers (Reich et al. 2007, Cherel et al. 2008, Newsome et al. 2010,
Ruiz-Cooley et al. 2010). Adult female sea turtles encountered at nesting beaches can be more easily sampled for stable isotope analysis of tissues than those at foraging grounds, and these samples can provide information about their diet and habitat use prior to migration to the nesting beach (Reich et al. 2010). There is a limited window of time in which to collect these samples, and if the female is not encountered on the nesting beach, the collection opportunity is lost. 
However, if offspring isotope composition reflects the maternal composition, sampling offspring could provide an opportunity to gain information about maternal foraging patterns without having to encounter the nesting female, thus increasing potential sample size. The difference in isotope values between maternal and offspring tissue is identified as the discrimination factor, and a reliable estimate of these values would be necessary to determine maternal isotope composition. Information regarding ecological and behavioral patterns could have significant implications for conservation of this endangered species.

Carbon and nitrogen stable isotope ratios $\left(\delta^{13} \mathrm{C}\right.$ and $\delta^{15} \mathrm{~N}$ ) reflect diet and habitat use, providing insight into an organism's trophic relationships and general foraging patterns (Hobson 1999). Additionally, animal movement and migration can be inferred through isotope analysis, as isotope values can vary with latitude and geographic location (Rubenstein \& Hobson 2004, Graham et al. 2010). Consumer $\delta^{15} \mathrm{~N}$ values often increase 3 to $5 \%$ from their food source due to preferential excretion of light isotopes, causing a trophic shift in $\delta^{15} \mathrm{~N}$ values (Post 2002). Neonate tissues are derived from maternal resources and nutrients, which influences their stable isotope composition (Pilgrim 2007). Offspring, and particularly those that nurse, are expected to have $\delta^{15} \mathrm{~N}$ values that are up to 1 trophic level higher than their mothers' because offspring are essentially 'consuming' their mothers (Jenkins et al. 2001). For non-nursing offspring, this discrimination factor might be smaller, as the offspring were derived from maternal resources but do not have continued input through development. Lower $\delta^{13} \mathrm{C}$ values are expected in offspring compared to maternal values. Nutrients used to create offspring tissues are often derived from maternal lipid stores, and lipid $\delta^{13} \mathrm{C}$ values are often lower than other tissues (Post et al. 2007).

Measures of discrimination factors between mothers and offspring in oviparous species are sparse. Wolf spider Pardosa lugubris mother-offspring discrimination factors were variable depending on female diet and order of the egg sacs (Rickers et al. 2006). Previous studies on sea turtles have used stable isotope values of loggerhead egg yolks to examine female foraging patterns and trophic relationships (Godley et al. 1998, Hatase et al. 2002, Zbinden et al. 2011). Stable isotope values in loggerhead female keratin were significantly correlated to those in egg yolk (Zbinden et al. 2011), and stable isotope values in leatherback female blood components were also positively correlated to those in egg yolk (Caut et al. 2008). However, mother-offspring discrimination factors have not been reported for epidermis tissue.

The present study had 3 main aims. First, we measured carbon and nitrogen discrimination factors between female loggerhead turtles and their offspring. Loggerhead hatchlings were expected to have higher $\delta^{15} \mathrm{~N}$ values compared to their mothers, as eggs are derived from maternal nutrients, but a difference as large as 3 to $4 \%$, similar to a trophic shift, was not expected. Lower $\delta^{13} \mathrm{C}$ values were expected in hatchlings because sea turtle eggs are created largely from lipid stores (Hamann et al. 2002). Second, we examined whether samples from hatchlings found post mortem in their nests yield reliable values. As decomposition has been shown to significantly affect $\delta^{13} \mathrm{C}$ and $\delta^{15} \mathrm{~N}$ values (Ponsard \& Amlou 1999), we compared discrimination factors for freshly dead hatchlings to those found dead in the nest. Third, we evaluated the consistency of $\delta^{13} \mathrm{C}$ and $\delta^{15} \mathrm{~N}$ values among hatchlings from the same nest.

\section{MATERIALS AND METHODS}

Epidermis samples were collected on Wassaw Island, Georgia, USA, during the nesting seasons (May to September) in 2006 and 2009 from 29 nesting loggerheads and 47 hatchlings (for 3 females, 5 hatchlings were sampled to examine consistency). Hatchlings were either sacrificed for a separate study conducted by researchers at Georgia Southern University or were found dead in the nest when nests were excavated approximately $3 \mathrm{~d}$ post emergence. No turtles were sacrificed for the present study. Skin samples were taken from between the neck and the front flipper in the 'shoulder' area of each adult and hatchling turtle using sterile $6 \mathrm{~mm}$ biopsy punches and were stored at room temperature in $70 \%$ ethanol. Females may lay several clutches throughout the nesting season. Thus, the date of sample collection from the female was not always the same as the oviposition date for the nest from which hatchlings were collected. The time difference ranged from 0 to $50 \mathrm{~d}$ (mode $=0$ ).

For stable isotope analysis, samples were rinsed with distilled water and cleaned with isopropyl alcohol swabs. Surface epidermis was removed and homogenized with a scalpel blade, and samples were dried at $60^{\circ} \mathrm{C}$ for a minimum of $24 \mathrm{~h}$. An accelerated solvent extractor was used to remove lipids from the samples with petroleum ether solvent. Samples weighing 0.5 to $0.6 \mathrm{mg}$ were loaded into sterile $4 \times 6 \mathrm{~mm}$ tin capsules prior to stable isotope analysis. 
All samples were combusted in an ECS 4010 elemental analyzer (Costech) interfaced via a ConFlo III device to a DeltaPlus XL isotope ratio mass spectrometer (ThermoFinnigan). Delta notation was used to express stable isotope abundances, defined as parts per thousand $(\%)$ relative to the standard:

$$
\delta=\frac{R_{\text {sample }}}{R_{\text {standard }}}-1 \times 1000
$$

where $R_{\text {sample }}$ and $R_{\text {standard }}$ are corresponding ratios of heavy to light isotopes $\left({ }^{13} \mathrm{C}:{ }^{12} \mathrm{C}\right.$ and $\left.{ }^{15} \mathrm{~N}:{ }^{14} \mathrm{~N}\right)$ in the sample and international standard, respectively. Vienna Pee Dee Belemnite (VPDB) was used as the standard for ${ }^{13} \mathrm{C}$ and atmospheric $\mathrm{N}_{2}$ for ${ }^{15} \mathrm{~N}$. The reference material USGS40 (L-glutamic acid) was used as a calibration standard in all runs. The standard deviation of the reference material was $0.09 \%$ for $\delta^{13} \mathrm{C}$ and $0.11 \%$ for $\delta^{15} \mathrm{~N}(\mathrm{n}=10)$. An additional laboratory reference material with similar isotopic composition to the samples in this study, loggerhead scute, was used to evaluate precision. The standard deviation of the laboratory reference material was $0.09 \%$ for $\delta^{13} \mathrm{C}$ and $0.21 \%$ for $\delta^{15} \mathrm{~N}(\mathrm{n}=6)$.

For 3 females, 5 hatchlings were available from the same nest to examine consistency within an egg clutch. However, in the comparison between females and hatchlings, only 1 hatchling was used by random selection if more than 1 hatchling was available from the same nest. Discrimination factors $(\Delta)$ were calculated by subtracting female $\delta^{13} \mathrm{C}$ and $\delta^{15} \mathrm{~N}$ values from those of the hatchlings $\left(\Delta=\delta_{\text {hatchling }}-\delta_{\text {female }}\right)$. A Hotelling's $T^{2}$-test was used to examine $\Delta^{13} \mathrm{C}$ and $\Delta \Delta^{15} \mathrm{~N}$ differences simultaneously in dead-in-nest and fresh-dead hatchlings. An F-test was used to compare variance in discrimination factors between the 2 hatchling types. Linear regressions were used to examine the relationship between time elapsed from the date of female sampling to the date of oviposition as well as relationships between carbon and nitrogen isotope composition between hatchlings and females. All statistical analyses were performed using $R^{\circledR}$ (R Development Core Team 2011).

\section{RESULTS}

Female $\delta^{13} \mathrm{C}$ values ranged from -17.1 to $-14.1 \%$ (mean: $-15.9 \%$ ), and $\delta^{15} \mathrm{~N}$ values ranged from 11.0 to 18.0\%o (mean: 14.0\%) (Fig. 1). Hatchlings generally had lower $\delta^{13} \mathrm{C}$ values $(-18.7$ to $-15.0 \%$, mean: $-16.9 \%$ ) than females and a wider range of $\delta^{15} \mathrm{~N}$ values (10.5 to $18.4 \%$, mean: $14.3 \%$ ). Whether the hatchling was freshly dead or found dead in the nest affected the hatchling-female discrimination factors (Fig. 2, Table 1). The 2 groups had significantly different $\Delta^{13} \mathrm{C}$ and $\Delta^{15} \mathrm{~N}$ values $\left(T^{2}=5.39, \mathrm{df}_{1}=2, \mathrm{df}_{2}=\right.$ $31, \mathrm{p}<0.01)$. Discrimination factors for dead-in-nest hatchlings were also more variable than those of the fresh-dead group for both carbon $(F=0.29, p=0.029)$

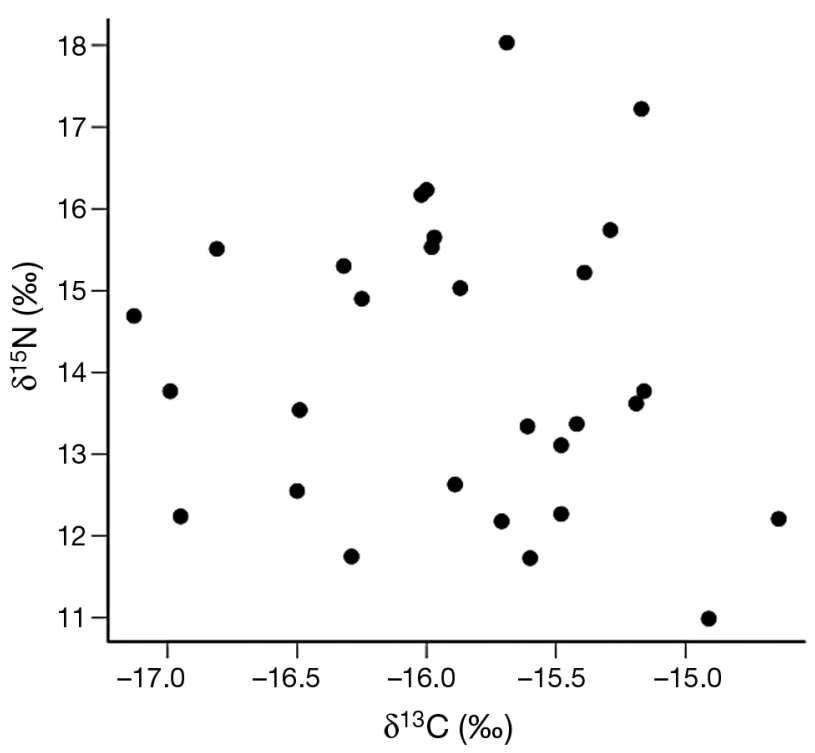

Fig. 1. Caretta caretta. Values of $\delta^{13} \mathrm{C}$ and $\delta^{15} \mathrm{~N}$ for epidermis samples from 29 adult female loggerheads

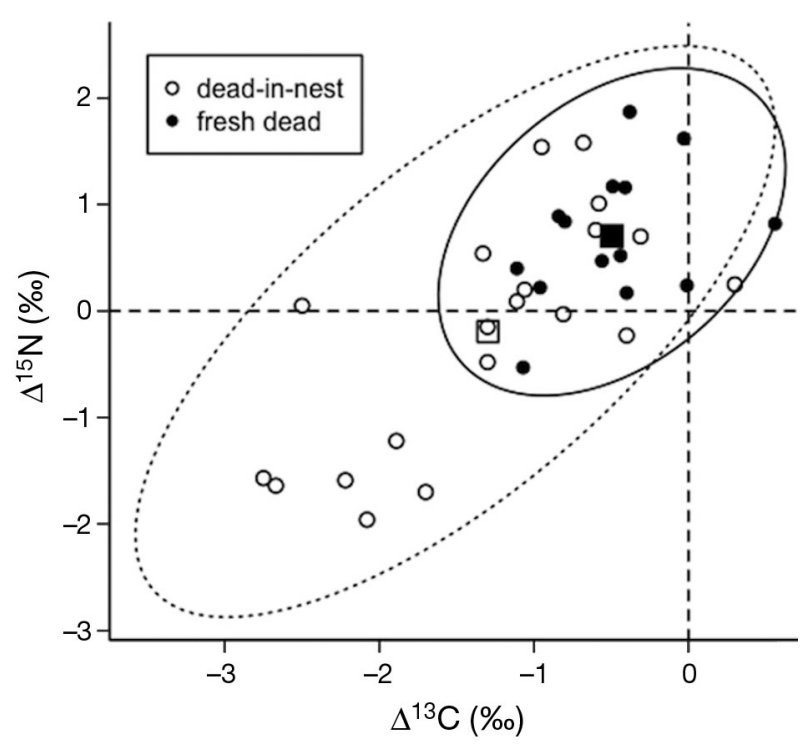

Fig. 2. Caretta caretta. Maternal $\delta^{13} \mathrm{C}$ and $\delta^{15} \mathrm{~N}$ values were subtracted from those of the hatchlings to determine hatchling-female discrimination factors $\left(\Delta^{13} \mathrm{C}\right.$ and $\left.\Delta^{15} \mathrm{~N}\right)$. The $95 \%$ bivariate confidence ellipse is represented by a solid line for fresh-dead hatchlings and a dotted line for dead-in-nest hatchlings. Dashed lines are drawn from 0 on both axes to indicate where there is no difference between females and offspring for carbon and nitrogen isotopic composition. Squares indicate mean discrimination factors 
Table 1. Caretta caretta. Mean \pm SD (\%) hatchling-female discrimination factors $(95 \%$ confidence intervals in parentheses) for each hatchling type

\begin{tabular}{|lccc|}
\hline Hatchling type & $\mathrm{n}$ & $\Delta{ }^{13} \mathrm{C}$ & $\Delta^{15} \mathrm{~N}$ \\
\hline Fresh-dead & 14 & $-0.50 \pm 0.46(-0.86,-0.13)$ & $0.70 \pm 0.63(0.34,1.07)$ \\
Dead-in-nest & 20 & $-1.30 \pm 0.85(-1.51,-1.08)$ & $-0.19 \pm 1.10(-0.49,0.10)$ \\
\hline
\end{tabular}

hatchling tissue did not result in a $\Delta^{13} \mathrm{C}$ factor as low as neonate rattlesnakes, with $\Delta^{13} \mathrm{C}=-1.2 \%$ o (Pilgrim 2007), but higher $\delta^{13} \mathrm{C}$ values were observed in the case of shark embryo muscle and liver compared to maternal tissue, with mean $\Delta^{13} \mathrm{C}$ $=1.5 \%$ for both tissues (McMeans

and nitrogen $(F=0.33, \mathrm{p}=0.045)$ (Table 1$)$. The discrimination factors for the fresh-dead hatchlings were significantly different from 0 .

The relationship between fresh-dead hatchling and female epidermis was also examined through linear regression. Female $\delta^{15} \mathrm{~N}$ values can be predicted from hatchling values using the linear equation $\delta^{15} \mathrm{~N}_{\text {female }}=1.02 \times \delta^{15} \mathrm{~N}_{\text {hatchling }}-1.02\left(\mathrm{r}^{2}=0.88\right.$, $\mathrm{df}=12, \mathrm{p}<0.001$ ) (Fig. 3a). Female $\delta^{13} \mathrm{C}$ values can be estimated using the equation $\delta^{13} \mathrm{C}_{\text {female }}=0.51 \times$ $\delta^{13} \mathrm{C}_{\text {hatchling }}-7.38\left(\mathrm{r}^{2}=0.24, \mathrm{p}=0.042\right)$ (Fig. 3b). While hatchling and female $\delta^{13} \mathrm{C}$ values are statistically correlated, we would suggest caution in applying this equation due to the small range in $\delta^{13} \mathrm{C}$ values and low $\mathrm{r}^{2}$ value.

Fresh-dead hatchlings from the same nest had high consistency, as indicated by low ranges and standard deviations in $\delta^{13} \mathrm{C}$ and $\delta^{15} \mathrm{~N}$ values (Table 2). The standard deviations were similar to those of our internal laboratory reference material (see 'Materials and methods'). The time range between the date epidermis was collected from the female and the oviposition date ranged from 0 to $50 \mathrm{~d}$. However, there was no effect of elapsed time on either $\Delta^{13} \mathrm{C}(t=-1.74, \mathrm{p}=$ $0.09)$ or $\Delta^{15} \mathrm{~N}(t=-1.20, \mathrm{p}=0.24)$ values.

\section{DISCUSSION}

Discrimination factors between most of the freshdead hatchlings and their corresponding mothers followed the expected pattern. Fresh-dead hatchlings had significantly higher $\delta^{15} \mathrm{~N}$ and significantly lower $\delta^{13} \mathrm{C}$ values compared to their respective mothers, resulting in discrete hatchling-female discrimination factors $\left(\Delta^{13} \mathrm{C}=-0.50 \%\right.$ and $\Delta^{15} \mathrm{~N}=$ $0.70 \%$, see Table 1). The mother-offspring $\Delta^{15} \mathrm{~N}$ factors in our study are somewhat lower than those of other studies of non-nursing offspring, with values ranging from 0.82 to $1.7 \%$ in shark embryos (McMeans et al. 2009, Vaudo et al. 2010). Motheroffspring $\Delta^{13} \mathrm{C}$ factors are more variable in other studies of non-nursing offspring, depending on the species and tissue (Pilgrim 2007, McMeans et al. 2009, Vaudo et al. 2010). Fresh-dead loggerhead et al. 2009). Loggerhead hatchling-female discrimination for fresh-dead hatchlings was similar to that reported for the black tip shark Carcharhinus limbatus embryo-female discrimination factors (Vaudo et al. 2010) with $\Delta^{13} \mathrm{C}=-0.27 \%$ and $\Delta^{15} \mathrm{~N}=$ $0.88 \%$.
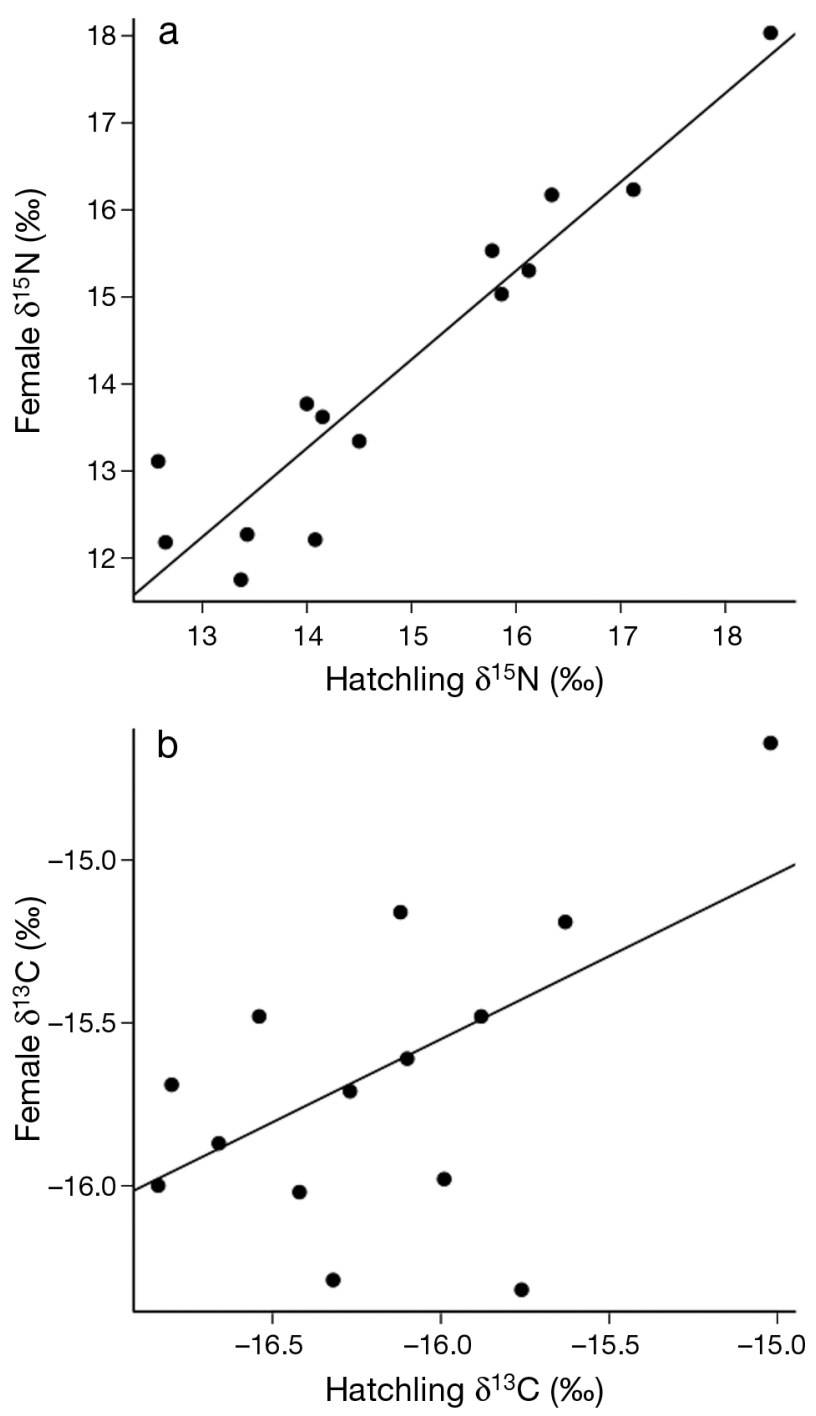

Fig. 3. Caretta caretta. Relationships of female and hatchling (a) $\delta^{15} \mathrm{~N}$ and (b) $\delta^{13} \mathrm{C}$ epidermis values for fresh-dead hatchlings only. The regression equations for $\delta^{15} \mathrm{~N}$ and $\delta^{13} \mathrm{C}$ values are given in the 'Results' section 
Table 2. Caretta caretta. Range $\pm \mathrm{SD}(\%)$ in $\delta^{13} \mathrm{C}$ and $\delta^{15} \mathrm{~N}$ values for 3 groups of fresh-dead hatchlings from different mothers. Each group consisted of 5 hatchlings from the same nest

\begin{tabular}{|lll|}
\hline \multirow{2}{*}{ Female tag } & \multicolumn{2}{c|}{ Hatchling } \\
\cline { 2 - 3 } & $\delta^{13} \mathrm{C}$ range & $\delta^{15} \mathrm{~N}$ range \\
\hline RRG330 & $0.21 \pm 0.08$ & $0.38 \pm 0.14$ \\
TTG263 & $0.51 \pm 0.21$ & $0.33 \pm 0.14$ \\
TTG393 & $0.31 \pm 0.12$ & $0.25 \pm 0.11$ \\
\hline
\end{tabular}

Many comparisons between females and offspring have calculated discrimination factors (Sare et al. 2005, McMeans et al. 2009, Vaudo et al. 2010), while the only other comparisons for sea turtle females and offspring (egg yolks) have used linear regression (Caut et al. 2008, Zbinden et al. 2011). A slope different from 1 means that the discrimination between mother and offspring will vary over a range of isotope values, so that applying a discrimination factor may yield less reliable results. In the present study, the slope relating female and hatchling epidermis $\delta^{15} \mathrm{~N}$ values is much closer to 1 than what has been reported previously for mother-offspring isotopic relationships in sea turtles (Caut et al. 2008, Zbinden et al. 2011).

Hatchling-female $\Delta^{13} \mathrm{C}$ and $\Delta^{15} \mathrm{~N}$ factors were significantly lower for hatchlings found dead in the nest than for freshly dead hatchlings, likely due to tissue decomposition. Few studies have quantified the effect of decomposition on stable isotope values, and the direction and magnitude of change due to decomposition are not consistent. In Drosophila melanogaster tissue, rotting resulted in lower $\delta^{13} \mathrm{C}$ values and higher $\delta^{15} \mathrm{~N}$ values (Ponsard \& Amlou 1999). Values of $\delta^{15} \mathrm{~N}$ in potentially degraded loggerhead egg yolk (measured in undeveloped eggs collected at posthatching clutch excavation) were higher compared to fresh yolk, while changes in $\delta^{13} \mathrm{C}$ values were mixed (Zbinden et al. 2011). Finally, greater variation was observed in $\delta^{13} \mathrm{C}$ and $\delta^{15} \mathrm{~N}$ values of skin from decomposing sea lion carcasses, though measuring such effects was not the focus of the study (Todd et al. 2010). In our study, it is likely that decay significantly affects stable isotope values in hatchling tissues and leads to larger confidence intervals in the discrimination factors, thus fresh samples are preferable.

Obtaining fresh samples does not require hatchling sacrifice. Epidermis could be sampled from live hatchlings using a smaller, $2 \mathrm{~mm}$ biopsy punch. Repeated sampling of skin did not affect growth rates and health status of hatchling loggerheads (Bjorndal et al. 2010). Additionally, the high consistency among loggerhead hatchlings from the same nest allows for smaller sample sizes, as stable isotope analysis of multiple samples from a nest quickly increases analysis costs. Similar consistency has been observed in loggerhead egg yolk within and among clutches from the same female (Zbinden et al. 2011) and in offspring of wolf spiders from the same eggsac (Rickers et al. 2006). In the case of sea turtles, eggs are formed at approximately the same time from the female's nutrient stores (Miller 1997), so it is not surprising that hatchlings from the same clutch are consistent in their stable isotope ratios. Based on our results, we believe stable isotope analysis of epidermis sampled from a single live hatchling provides an acceptable estimate for the whole nest and - with the discrimination factor - the mother. We expect that these discrimination factors would be applicable to other loggerhead populations, although we do not have any data to suggest that they are applicable across species.

Variation in the discrimination factors was observed even for the fresh-dead hatchlings. Some of this variation may be due to physiological differences between females, known as inherent variation, so that even when individuals are fed the same diet, tissue - or in this case, offspring - differences in stable isotope composition are observed (Barnes et al. 2008). In a recently completed study, inherent variation in epidermis tissue from juvenile and adult green turtles Chelonia mydas was measured and incorporated into estimates of diet-tissue discrimination (Vander Zanden et al. unpubl.). The variation associated with diet-tissue discrimination in that study is very similar to the female-hatchling discrimination value variation observed in the present study. Another possible cause is diet quality, as a positive trend between diet $\mathrm{C}: \mathrm{N}$ ratios and nitrogen diet-tissue discrimination has been observed in a variety of species (Robbins et al. 2005), although this has not been tested for mother-offspring discrimination.

Hatchling-female discrimination factors reported here can be applied in future field work and sample collections on loggerhead nesting beaches to determine female isotope composition from hatchling samples. Application of the discrimination factors can be useful when epidermis samples from nesting females are not available, although we would recommend using fresh samples when available. Investigating hatchling isotope composition alone can therefore provide essential foraging and migration information regarding female loggerheads without encountering them. This is especially pertinent to aiding conservation of an endangered species such as the loggerhead turtle, and may have future implications for other species, as well. 
Acknowledgements. We thank the Caretta Research Project field crew for sample collection, J. Curtis in the Light Stable Isotope Lab at the University of Florida, Gainesville, FL, for stable isotope analysis, and J. M. Ponciano for help with statistical analyses. H.B.V.Z. was supported by an NSF Graduate Research Fellowship. Funds for analyses were provided by the National Fish and Wildlife Foundation, U.S. National Marine Fisheries Service, and U.S. Fish and Wildlife Service. Samples were collected in compliance with the Institutional Animal Care and Use Committee at the University of Florida and the Georgia Department of Natural Resources.

\section{LITERATURE CITED}

Barnes C, Jennings S, Polunin NVC, Lancaster JE (2008) The importance of quantifying inherent variability when interpreting stable isotope field data. Oecologia 155:227-235

Bjorndal KA (1997) Foraging ecology and nutrition of sea turtles. In: Lutz PL, Musick JA (eds) The biology of sea turtles. CRC Press, Boca Raton, FL, p 199-230

Bjorndal KA, Reich KJ, Bolten AB (2010) Effect of repeated tissue sampling on growth rates of juvenile loggerhead turtles Caretta caretta. Dis Aquat Org 88:271-273

Caut S, Fossette S, Guirlet E, Angulo E, Das K, Girondot M, Georges JY (2008) Isotope analysis reveals foraging area dichotomy for Atlantic leatherback turtles. PLoS ONE 3: e1845

Cherel Y, Le Corre M, Jaquemet S, Ménard F, Richard P, Weimerskirch H (2008) Resource partitioning within a tropical seabird community: new information from stable isotopes. Mar Ecol Prog Ser 366:281-291

> Godley BJ, Thompson DR, Waldron S, Furness RW (1998) The trophic status of marine turtles as determined by stable isotope analysis. Mar Ecol Prog Ser 166:277-284

Graham BS, Koch PL, Newsome SE, McMahon KW, Aurioles D (2010) Using isocapes to trace the movements and foraging behavior of top predators in oceanic ecosystems. In: West JB, Bowen GJ, Dawson TE (eds) Isoscapes: understanding movement, pattern, and process on earth through isotope mapping. Springer, Berlin, p 299-318

> Hamann M, Limpus CJ, Whittier JM (2002) Patterns of lipid storage and mobilisation in the female green sea turtle (Chelonia mydas). J Comp Physiol B Biochem Syst Environ Physiol 172:485-493

> Hatase H, Takai N, Matsuzawa Y, Sakamoto W and others (2002) Size-related differences in feeding habitat use of adult female loggerhead turtles Caretta caretta around Japan determined by stable isotope analyses and satellite telemetry. Mar Ecol Prog Ser 233:273-281

> Hobson K (1999) Tracing origins and migration of wildlife using stable isotopes: a review. Oecologia 120:314-326

Jenkins S, Partridge S, Stephenson T, Farley S, Robbins C (2001) Nitrogen and carbon isotope fractionation between mothers, neonates, and nursing offspring. Oecologia 129:336-341

McMeans BC, Olin JA, Benz GW (2009) Stable-isotope comparisons between embryos and mothers of a placentatrophic shark species. J Fish Biol 75:2464-2474

Editorial responsibility: Brendan Godley, University of Exeter, Cornwall Campus, UK
Miller JD (1997) Reproduction in sea turtles. In: Lutz PL, Musick JA (eds) The biology of sea turtles. CRC Press, Boca Raton, FL, p 51-82

Newsome SD, Clementz MT, Koch PL (2010) Using stable isotope biogeochemistry to study marine mammal ecology. Mar Mamm Sci 26:509-572

Pilgrim MA (2007) Expression of maternal isotopes in offspring: implications for interpreting ontogenetic shifts in isotopic composition of consumer tissues. Isotopes Environ Health Stud 43:155-163

Ponsard S, Amlou M (1999) Effects of several preservation methods on the isotopic content of Drosophila samples. CR Acad Sci Ser III Sci Vie 322:35-41

> Post DM (2002) Using stable isotopes to estimate trophic position: models, methods, and assumptions. Ecology 83: 703-718

Post DM, Layman CA, Arrington DA, Takimoto G, Quattrochi J, Montana CG (2007) Getting to the fat of the matter: models, methods and assumptions for dealing with lipids in stable isotope analyses. Oecologia 152: 179-189

R Development Core Team (2011) R: a language and environment for statistical computing. R Foundation for Statistical Computing, Vienna. Available at: www.Rproject.org

Reich KJ, Bjorndal KA, Bolten AB (2007) The 'lost years' of green turtles: using stable isotopes to study cryptic lifestages. Biol Lett 3:712-714

Reich KJ, Bjorndal KA, Frick MG, Witherington BE, Johnson C, Bolten AB (2010) Polymodal foraging in adult female loggerheads (Caretta caretta). Mar Biol 157:113-121

> Rickers S, Langel R, Scheu S (2006) Dietary routing of nutrients from prey to offspring in a generalist predator: effects of prey quality. Funct Ecol 20:124-131

$>$ Robbins CT, Felicetti LA, Sponheimer M (2005) The effect of dietary protein quality on nitrogen isotope discrimination in mammals and birds. Oecologia 144:534-540

> Rubenstein DR, Hobson KA (2004) From birds to butterflies: animal movement patterns and stable isotopes. Trends Ecol Evol 19:256-263

> Ruiz-Cooley RI, Villa EC, Gould WR (2010) Ontogenetic variation of $\delta^{13} \mathrm{C}$ and $\delta^{15} \mathrm{~N}$ recorded in the gladius of the jumbo squid Dosidicus gigas: geographic differences. Mar Ecol Prog Ser 399:187-198

> Sare DTJ, Miller JS, Longstaffe FJ (2005) Nitrogen- and carbon-isotope fractionation between mothers and offspring in red-backed voles (Clethrionomys gapperi). Can J Zool 83:712-716

Todd SK, Holm B, Rosen DA, Tollit DJ (2010) Stable isotope signal homogeneity and differences between and within pinniped muscle and skin. Mar Mamm Sci 26:176-185

Vaudo JJ, Matich P, Heithaus MR (2010) Mother-offspring isotope fractionation in two species of placentatrophic sharks. J Fish Biol 77:1724-1727

> Zbinden JA, Bearhop S, Bradshaw P, Gill B, Margaritoulis D, Newton J, Godley BJ (2011) Migratory dichotomy and associated phenotypic variation in marine turtles revealed by satellite tracking and stable isotope analysis. Mar Ecol Prog Ser 421:291-302

Submitted: October 24, 2011; Accepted: December 30, 2011 Proofs received from author(s): May 1, 2012 